\title{
Effect of Nano Silicon Dioxide Coating Films on the Quality Characteristics of Fresh-Cut Cantaloupe
}

\author{
Rokayya Sami ${ }^{1, * \mathbb{C}}$, Manal Almatrafi ${ }^{1}$, Abeer Elhakem ${ }^{2}$, Mona Alharbi ${ }^{2}$, Nada Benajiba ${ }^{3}$ and Mahmoud Helal ${ }^{4}$ \\ 1 Department of Food Science and Nutrition, College of Sciences, Taif University, Box P.O. 11099, \\ Taif 21944, Saudi Arabia; manal.almatrafi@uconn.edu \\ 2 Department of Biology, College of Science and humanities in Al-Kharj, Prince Sattam Bin \\ Abdulaziz University, Al-Kharj 11942, Saudi Arabia; a.elhakem@psau.edu.sa (A.E.); \\ mh.alharbi@psau.edu.sa (M.A.) \\ 3 Department of Basic Health Sciences, Deanship of Preparatory Year, Princess Nourah Bint \\ Abdulrahman University, P.O. Box 84428, Riyadh 11671, Saudi Arabia; nabenajiba@pnu.edu.sa \\ 4 Department of Mechanical Engineering, Faculty of Engineering, Taif University, Box P.O. 11099, \\ Taif 21944, Saudi Arabia; helal.mo@tu.edu.sa \\ * Correspondence: rokayya.d@tu.edu.sa
}

check for

updates

Citation: Sami, R.; Almatrafi, M.; Elhakem, A.; Alharbi, M.; Benajiba, N.; Helal, M. Effect of Nano Silicon Dioxide Coating Films on the Quality Characteristics of Fresh-Cut Cantaloupe. Membranes 2021, 11, 140. https:// doi.org/10.3390/membranes11020140

Received: 5 January 2021

Accepted: 15 February 2021

Published: 17 February 2021

Publisher's Note: MDPI stays neutral with regard to jurisdictional claims in published maps and institutional affiliations.

Copyright: (C) 2021 by the authors Licensee MDPI, Basel, Switzerland. This article is an open access article distributed under the terms and conditions of the Creative Commons Attribution (CC BY) license (https:// creativecommons.org/licenses/by/ $4.0 /)$.

\begin{abstract}
The prime objective of the research was to explore the coating effects of chitosan and nanosilicon dioxide with nisin as an antimicrobial agent on physicochemical properties, microbiological stability, and sensorial quality changes during the storage at $4{ }^{\circ} \mathrm{C}$. The combination of nano-material and chitosan in addition to nisin was effective for reducing the postharvest attributes of fresh-cut cantaloupes in addition to the highest score in sensory evaluation. Chitosan coating treatment enhanced the microbiological quality $2.50 \mathrm{log}$ CFU/g and $1.87 \mathrm{log}$ CFU/g for aerobic counts and mold/yeasts populations, respectively. In a word, the combination of chitosan/nano-silica/nisin treatment was the best condition for fresh-cut cantaloupe shelf life extension by maintaining color, vitamin C $22.29 \mathrm{mg} / 100 \mathrm{~g}$, peroxidase activity $8.06 \mathrm{U} / \mathrm{min} . \mathrm{g}$, and other microbiological tests up to storage time of 8 days.
\end{abstract}

Keywords: chitosan; nano-silicon dioxide; shelf-life; cantaloupe; microbial activity

\section{Introduction}

Fresh-cut products make easy access to meet the demands of consumers for vegetables and fruits [1]. Cantaloupe (Cucumis melo L.) is an example, requiring preparation before eating due to its too large size [2]. Fruit quality properties such as color, texture, and microbial quality are the top priority because of consumption and fetching commercial profits [3]. Cantaloupe is an excellent vitamin $C$ and $\beta$-carotene source; it also provides additional nutritional values of iron, potassium, and dietary fiber [4]. Some of the common and cost-effective methods are used for developing the quality of cantaloupe products includes the packaging by ultraviolet light [5,6], gamma radiation [7], chemical treatments [8], edible coatings [9], and multilayered edible coatings using nanotechnology [10]. This coating technique could be perfect for overcominge quality problems [11]. Chitosan is recognized due to its antimicrobial activity and hybrid film properties [12]. Nutrients, colorants, antioxidants, antimicrobials, and flavors can be included in the films and discharged in an organized manner [13]. Another food additive; nano-silicon dioxide, has been approved for safety rating which cannot be digestible by humans [14,15]. Earlier research works reported chitosan and nano-silicon dioxide coatings to reduce browning of jujube, papaya, longan, and apple fruits [16-19]. Nisin is defined as an antimicrobial peptide and approved by (FAO/WHO) as one of the common safe food additives for different types of foods [20].

Therefore, according to the advantage of eco-friendly and cost-effective coating techniques, the present work aimed to indicate the efficiency of chitosan/nano-silica/nisin coating to improve fresh-cut cantaloupe preservation quality at $4{ }^{\circ} \mathrm{C}$ of storage. 


\section{Materials and Methods}

\subsection{Materials}

Chitosan deacetylation medium of $85 \%$ molecular weight, acetic acid, and glycerol were purchased from Jinde Haidebei Marine Biological Engineering Co., Ltd., Tangshan, China. Tetraorthosilicate (TEOS) as nano-SiO${ }_{2}$ and Nisin were supplied by Caofeidian Taihongshengda New Material Co. (Tangshan, China). All other chemicals belong to the analytical grade.

\subsection{Fruits}

A total number of 4 batches of cantaloupes melon were procured from a local commercial fruit store, washed with running water, peeled, dissected into $30 \times 30 \times 30(\mathrm{~mm})$ slices, and stored in a refrigerator at a storage temperature of $4{ }^{\circ} \mathrm{C}$ with $65 \%$ relative humidity.

\subsection{Preparation of Hybrid Coating Film}

Chitosan (1\%) was dissolved in $1 \%$ acetic acid and $0.5 \%$ glycerol. The solution was stirred $10 \mathrm{~h}$ at $300 \mathrm{rpm}$, centrifuged at $4{ }^{\circ} \mathrm{C}$ for $30 \mathrm{~min}$ to separate the supernatants and remove insoluble particles. The same amount of this solution was taken and $1 \%$ of TEOS was added in a $500 \mathrm{~mL}$ flask. Nisin was dissolved in a chitosan/nano-silica solution containing $0.02 \mathrm{~mol} / \mathrm{L}$ hydrochloric acid.

\subsection{Treatment of Fresh-Cut Cantaloupe Fruit}

The cut fruit pieces were distributed into four groups randomly as follows: control (deionized water); chitosan (CTS); chitosan/nano-silica (Nano/CTS) and chitosan/nanosilica/nisin (Nano/CTS/N). The fresh-cut cantaloupe fruit samples were dipped into different solutions for $5 \mathrm{~min}$ and allowed to be dry before chilling at $4{ }^{\circ} \mathrm{C}$.

\subsection{Shelf-Life Analysis}

Fresh-cut cantaloupe samples were placed in polyethylene zipper bags, having a 0.02 -millimeter thickness and kept at $4{ }^{\circ} \mathrm{C}$. Physical, chemical, microbial, and sensorial parameters were carried out at different intervals of storage days $0,2,4,6$, and 8 in refrigeration.

\subsubsection{Product Quality Parameters}

Fluid Loss

The fluid loss was measured according to the weights of juice and sample in the bag throughout the storage [2].

\section{Colour Determination}

The color was detected by a ZE-6000 Meter (Nippon, Japan). D65 light source and an $8 \mathrm{~mm}$ diameter measuring area were used [9].

\subsubsection{Physicochemical Quality Analysis}

$\mathrm{pH}$, Total Soluble Solids, Titratable Acidity, and Vitamin C Determinations

The $\mathrm{pH}$ value was measured at the ambient temperature (approximately $27^{\circ} \mathrm{C}$ ) from the cantaloupe juices by using a pH meter (Mettler Toledo Instruments Co., Shanghai, China) [21]. Total soluble solids content (TSS) was examined using a refractometer (Atago Pocket-refractometer PAL-BX/RI, Tokyo, Japan). Total acidity (TA) was detected by sodium hydroxide solution $(0.1 \mathrm{M})$ titration [22], and results were calculated as the percent of citric acid. Finally, vitamin $\mathrm{C}(\mathrm{Vc})$ was detected by iodine titration, and results were calculated as milligrams $/ 100 \mathrm{~g}$ of the sample [23].

Extraction of Malondialdehyde Content

A mass of selected tissue ( $3 \mathrm{~g}$ ) of fresh-cut-cantaloupe fruits was blended with $10 \mathrm{~mL}$ of $10 \%$ trichloroacetic acid to detect malondialdehyde content (MDA) [24]. The supernatant was blended with $2 \mathrm{~mL}$ of $0.5 \%$ 2-thiobarbituric acid, boiled for $20 \mathrm{~min}$ at $95^{\circ} \mathrm{C}$, immediately 
cooled, and then the supernatant was taken in a 96-well plate. The absorbance was evaluated at 450,532, and $600 \mathrm{~nm}$.

\section{Polyphenol Oxidase Enzyme Activity Determination}

Polyphenol oxidase (PPO) activity: $5 \mathrm{~mL}$ of $0.2 \mathrm{~mol} / \mathrm{L}$ with phosphate buffer ( $\mathrm{pH} 7)$ was added to $1 \mathrm{~mL} 0.1 \mathrm{~mol} / \mathrm{L}$ pyrocatechol solution and $1.95 \mathrm{~mL} 0.2 \mathrm{~mol} / \mathrm{L}$ with phosphate buffer ( $\mathrm{pH} 7$ ) [19]. The absorbance increase was measured every $20 \mathrm{~s}$ within 6 min after the addition of cantaloupe extract at $(410 \mathrm{~nm})$.

Peroxidase Enzyme Activity Determination

Peroxidase (POD) activity: $5 \mathrm{~mL}$ of $0.2 \mathrm{~mol} / \mathrm{L}$ with phosphate buffer $(\mathrm{pH} 7)$ was added to $0.15 \mathrm{~mL} 10 \mathrm{~g} / \mathrm{L}$ guaiacol, $0.15 \mathrm{~mL}$ volume fraction $1 \% \mathrm{H}_{2} \mathrm{O}_{2}, 2.66 \mathrm{~mL}$ with phosphate buffer (pH 7), and the absorbance at (460 nm) was measured every $20 \mathrm{~s}$ within 6 min [24].

\subsubsection{Microbiological Analysis and Water Activity Determination}

The analyses of the aerobic plate, yeast, and mold counts were carried out every 2 days until the storage period end [25]. Aerobic plate, yeasts, and molds performed using two Rose Bengal Mediums (RBM) (GB4789.15-2016) and (GB4789.2-2016) from Cell Bank (Biological Sciences, Shanghai, China). All the plates were incubated at $28{ }^{\circ} \mathrm{C}$ for 5 days. The obtained colonies were counted as log CFU (colony-forming units)/grams of cantaloupes at the incubation period ends. The water activity (Aw) was evaluated using a water activity meter (Aqualab, Decagon Devices, California, USA) [26].

\subsubsection{Sensory Analysis}

Sensory analysis was achieved consisting of students, qualified and experienced staff in College of Sciences with a range of (21-35) years. The assessment was done on the last day of the storage time. Panelists were given uniform amounts of each coating treatment to evaluate (color, odor, texture, flavor, and overall quality). Assessments were estimated according to the previous report of fresh-cut cantaloupe sensory determination [27].

\subsection{Statistical Analysis}

All the recorded data was recorded in triplicate and applied by using the SPSS Version 20.0 (SPSS Inc., U.S.A.). Significant differences were detected by Duncan's multiple tests.

\section{Results and Discussion}

\subsection{Effect of Coating Treatment on Fluid Loss and Colour Index}

Figure 1 shows fluid loss during chilled storage for fresh-cut cantaloupes. All samples lost their weight gradually due to moisture evaporation and respiration [28]. The fluid loss reached $\sim 4 \%$ at the end of the whole storage period. The same results were also reported [29]. The cantaloupe's color became significantly darker after the 2nd day of the storage for all the treatments except for Nano/CTS/N treatment, whose $L$ values decreasing from 38.53 to 23.42 (Table 1). Falade et al. [30] reported that enzymatic processes and weight loss may increase the pigment as $\beta$-carotene in watermelon. Zhang et al. [31] detected the same results for color determination. For $a$ and $b$ values, no differences were detected among all treatments, proposing that coating had no clear effects on the cantaloupe appearance. The results recommend that (Nano/CTS/N) treatment can help in maintaining cantaloupes color during the whole storage. 


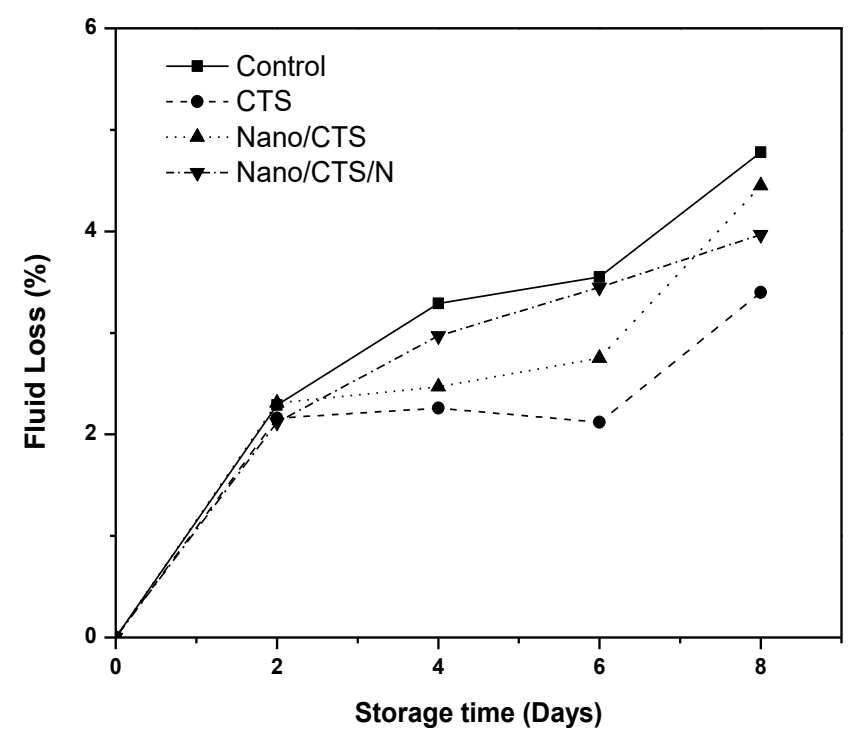

Figure 1. Effects of coating treatments on fluid loss for cantaloupes during storage at $4{ }^{\circ} \mathrm{C}$ for 8 days. Data are mean $\pm \mathrm{SD}, n=3$.

Table 1. Changes in $L^{*}$-values, $a^{*}$-values, and $b^{*}$-values of cantaloupe during storage.

\begin{tabular}{|c|c|c|c|c|}
\hline & Control & CTS & Nano/CTS & Nano/CTS/N \\
\hline \multicolumn{5}{|c|}{$L^{*}$-value } \\
\hline 0 & $\mathrm{~A} 38.53 \pm 0.45^{\mathrm{a}}$ & ${ }^{\mathrm{B}} 37.06 \pm 0.39^{\mathrm{a}}$ & $\mathrm{C}_{26.31 \pm 0.38^{\mathrm{b}}}$ & ${ }^{C} 26.20 \pm 1.34$ bc \\
\hline 2 & В $31.14 \pm 0.38^{\mathrm{b}}$ & $C_{2} 29.59 \pm 0.08^{c}$ & D $25.87 \pm 0.15 b c$ & A $31.64 \pm 0.04^{\mathrm{a}}$ \\
\hline 4 & A $27.91 \pm 0.55^{\mathrm{c}}$ & $C_{2} 22.91 \pm 0.33^{e}$ & ${ }^{\mathrm{A}} 28.18 \pm 0.17^{\mathrm{a}}$ & В $27.16 \pm 0.11^{b}$ \\
\hline 6 & $C_{23.05} \pm 0.32^{d}$ & A $26.16 \pm 0.58^{d}$ & $\mathrm{D} 21.05 \pm 0.14^{\mathrm{d}}$ & ${ }^{\mathrm{B}} 25.38 \pm 0.27^{\mathrm{c}}$ \\
\hline 8 & D $23.42 \pm 0.54^{d}$ & A $31.71 \pm 0.09^{b}$ & ${ }^{C} 25.39 \pm 0.52^{c}$ & B $26.93 \pm 0.08^{b}$ \\
\hline \multicolumn{5}{|c|}{$a^{*}$-value } \\
\hline 0 & $C_{17.56} \pm 0.38^{c}$ & $\mathrm{C}_{18.48} \pm 1.13^{\mathrm{b}}$ & A $26.77 \pm 0.18^{\mathrm{a}}$ & B $23.25 \pm 2.39$ bc \\
\hline 2 & A $20.04 \pm 0.12^{b}$ & В $19.41 \pm 0.28^{\mathrm{b}}$ & D $15.80 \pm 0.07^{c}$ & ${ }^{C} 17.44 \pm 0.16^{a}$ \\
\hline 4 & $\mathrm{AB} 14.91 \pm 0.14^{\mathrm{d}}$ & B $14.07 \pm 0.76^{\mathrm{d}}$ & A $16.72 \pm 1.83^{\mathrm{c}}$ & A $16.72 \pm 0.19^{b}$ \\
\hline 6 & $C^{C} 17.50 \pm 0.16^{c}$ & ${ }^{D} 16.34 \pm 0.54^{c}$ & A $23.37 \pm 0.23^{b}$ & ${ }^{\mathrm{B}} 21.23 \pm 0.17^{\mathrm{d}}$ \\
\hline 8 & A $25.39 \pm 0.39^{\mathrm{a}}$ & B $22.52 \pm 0.30^{\text {a }}$ & B $22.76 \pm 0.10^{\mathrm{b}}$ & ${ }^{C} 18.65 \pm 0.29^{c}$ \\
\hline \multicolumn{5}{|c|}{$b^{*}$-value } \\
\hline 0 & A $26.09 \pm 0.58^{a}$ & $\mathrm{AB} 24.33 \pm 2.78^{\mathrm{a}}$ & $\mathrm{AB} 24.40 \pm 0.87^{\mathrm{a}}$ & ${ }^{\mathrm{B}} 21.33 \pm 1.48^{\mathrm{a}}$ \\
\hline 2 & D $17.54 \pm 0.19^{d}$ & B $21.02 \pm 0.10$ bc & $\mathrm{C}_{19.84 \pm 0.05^{\mathrm{d}}}$ & 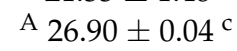 \\
\hline 4 & $\mathrm{C}_{21.24} \pm 0.31^{\mathrm{b}}$ & $\mathrm{D} 19.38 \pm 0.44^{\mathrm{c}}$ & A $23.56 \pm 0.25^{\mathrm{b}}$ & B $22.47 \pm 0.12^{b}$ \\
\hline 6 & ${ }^{\mathrm{B}} 20.02 \pm 0.36^{\mathrm{C}}$ & A $22.36 \pm 0.36^{\mathrm{ab}}$ & $\mathrm{D} 16.52 \pm 0.23^{\mathrm{e}}$ & ${ }^{C} 18.00 \pm 0.43^{c}$ \\
\hline 8 & $C_{17.53} \pm 0.26^{d}$ & A $21.56 \pm 0.17^{b c}$ & ${ }^{\mathrm{A}} 21.41 \pm 0.30^{\mathrm{c}}$ & ${ }^{B} 20.63 \pm 0.10^{c}$ \\
\hline
\end{tabular}

*Values within a column (lowercase) or row (uppercase) letter are significantly different ( $p \geq 0.05)$. CTS = chitosan, Nano/CTS = chitosan/nano-silica, and Nano/CTS/N = chitosan/nano-silica/nisin.

\subsection{Effect of Coating Treatment on $p H, T S S, T A$, and Vc Contents}

The application of the different coating treatments affected the chemical parameters of fresh-cut cantaloupes. The $\mathrm{pH}$ was in-between 5.67-5.99 during the inertial storage (Figure 2a). CTS treatment had a slightly lower $\mathrm{pH}$ value than the other treatments. All results were within the previous range of cantaloupe (5.5-6.5) [2]. All treatments had Brix values TSS in-between $\sim 9.56$ during the inertial storage and reached 8.07 to 9.4 by the end of the storage time (Figure 2b). Kaushlendra et al. [32], mentioned that cantaloupe sugar contents cannot be changed obviously as it is a non-climacteric fruit. 


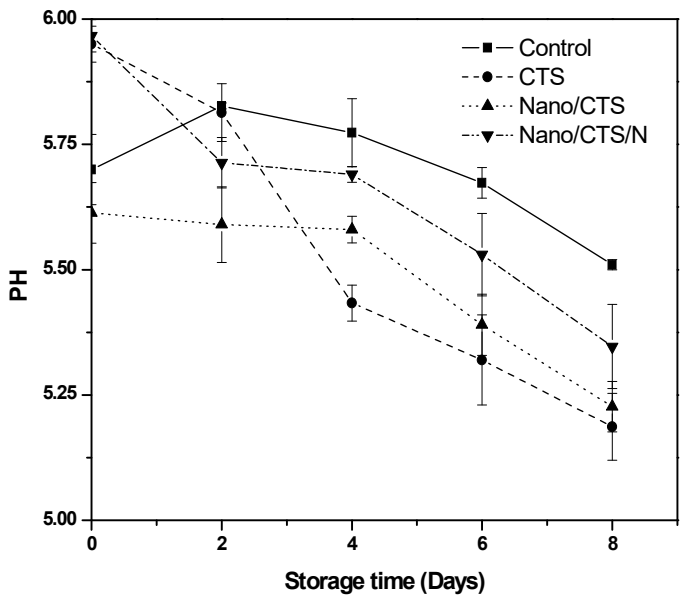

(a)

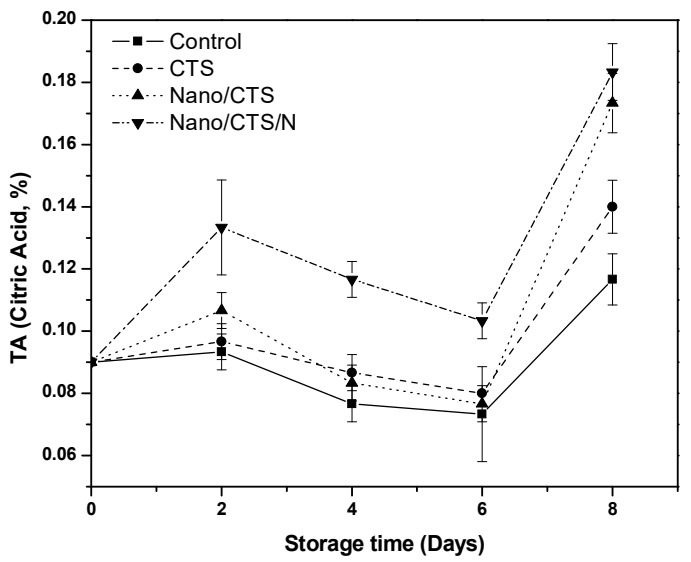

(c)

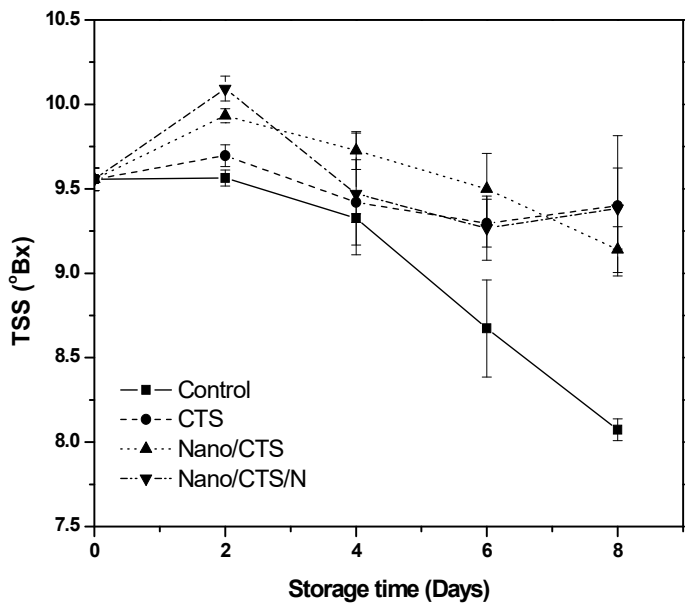

(b)

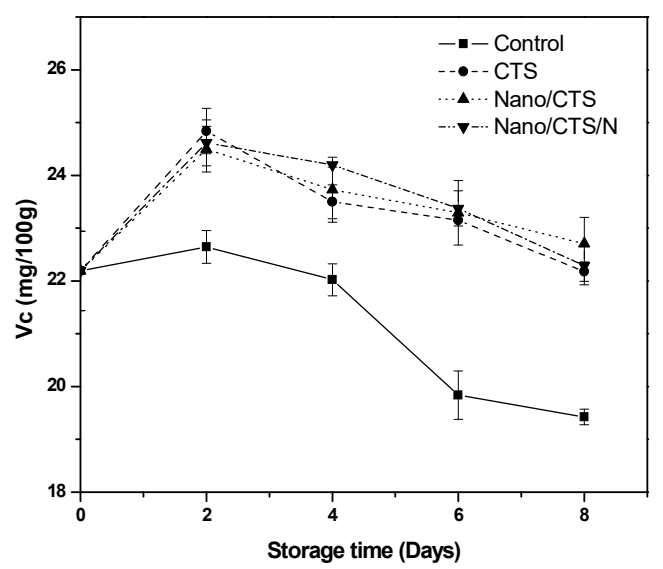

(d)

Figure 2. Effects of coating treatments on $\mathrm{pH}(\mathbf{a})$, total soluble solids (TSS) (b), total (TA) (c), and retention (Vc) (d) contents of cantaloupe fruit; data are mean $\pm \mathrm{SD}, n=3$.

Total (TA) of all fresh samples had $~ 0.09$ during the inertial storage. On the 8th day, TA values increased although independent of CTS and nano-materials in the different coating treatments (Figure 2c). The coating was operative in the ripening process delay for fresh-cut cantaloupe. Similar TA values were found [26]. The coating helped retention (Vc) in all the treatments, which showed a little increase from 22.19 to $22.71 \mathrm{mg} / 100 \mathrm{~g}$ (Figure 2d). Similar results were detected as vitamin C content increased until the 8th day then decreased significantly during the evaluation due to the respiration decreased rate and oxygen reduced [29].

\subsection{Effect of Coating Treatment on MDA Content}

MDA is often used as a sign of fruit damage progress due to the structural integrity and cell membrane lipid peroxide levels [33]. As shown in (Figure 3a), a constant increase was detected for the control samples, while the treatment of nano-material delayed MDA increases. CTS treatment had $0.22 \mathrm{nmol} / \mathrm{g}$, which was lower than the other samples by the end of the storage period. It suggested that all nano-treatments can inhibit the peroxidation of lipids during storage. 


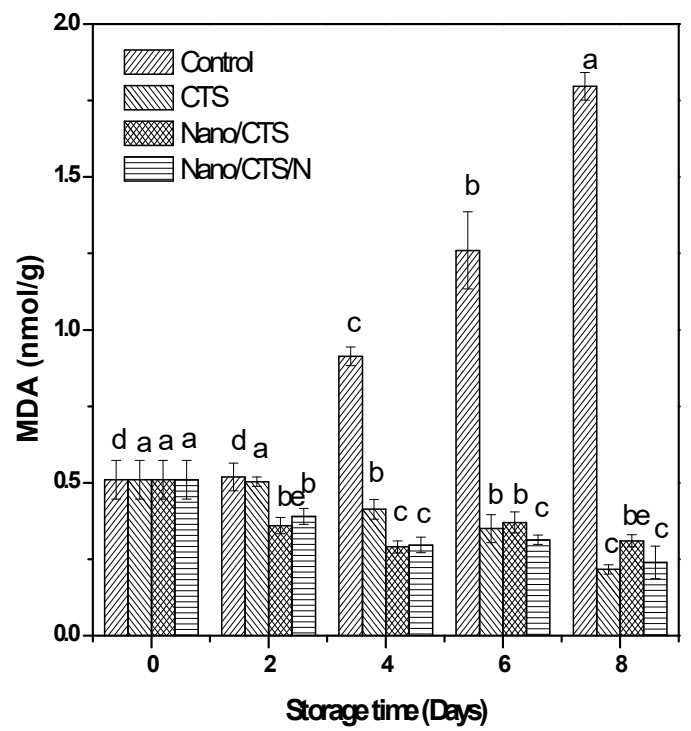

(a)

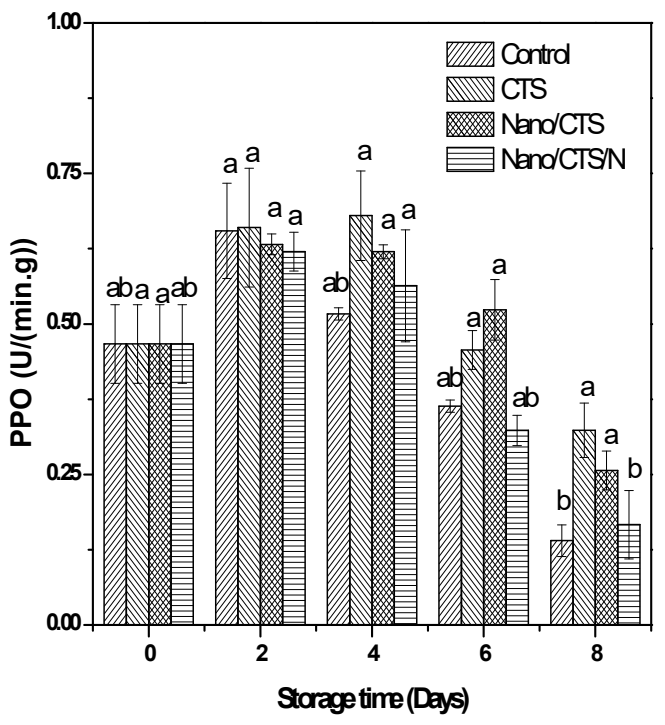

(b)

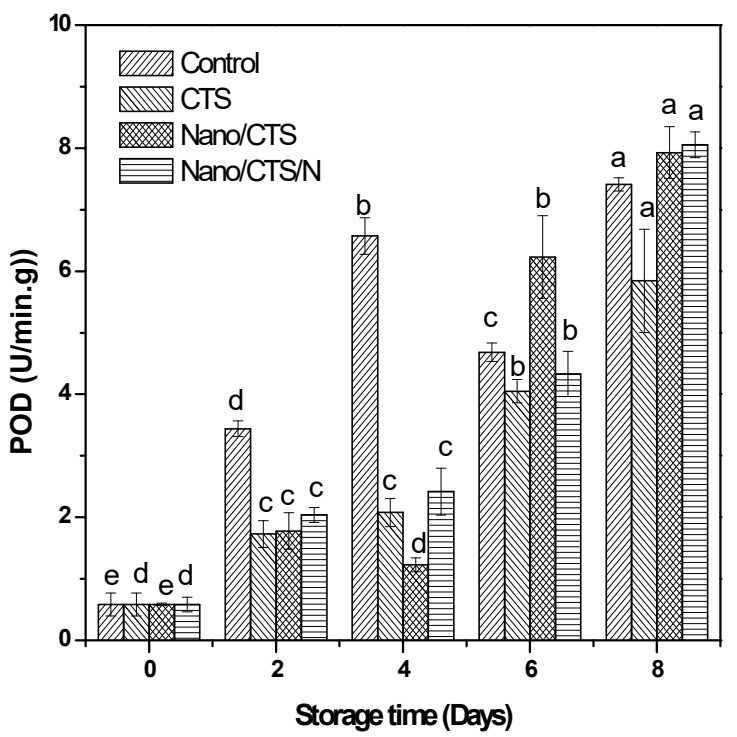

(c)

Figure 3. Effects of coating treatments on malondialdehyde content (MDA) (a), polyphenol oxidase (PPO) (b) and peroxidase

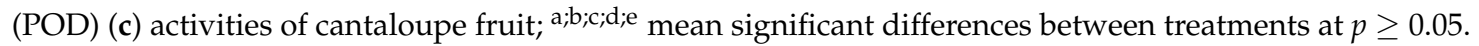

\subsection{Effect of Coating Treatment on PPO and POD Enzyme Activities}

As shown in (Figure 3b), PPO enzyme activities ascended radically in all the treatments during the storage which reached the maximum $0.14 \mathrm{U} / \mathrm{min} . \mathrm{g}$ for control on the 8 th day. CTS treatment reached $0.68 \mathrm{U} / \mathrm{min} . \mathrm{g}$ on the 4 th day, comparing with Nano/CTS $0.52 \mathrm{U} / \mathrm{min} . \mathrm{g}$ on the 6th day, while Nano/CTS/N recorded the lowest PPO activity by the end of the whole storage. These results were in agreement with the PPO observation, where it is reported that the maintenance of POD activity in Nano/CST and Nano/CST/N treatments increased due to the presence of consistent abiotic stress in the cantaloupe pieces during storage [34]. PPO values detected in grape and strawberry preserved by nano-materials and CTS also showed less damage than the control $[24,35]$. 
CTS treatment had the lowest POD enzyme activity as $(5.84 \mathrm{U} / \mathrm{min} . \mathrm{g})$ comparing the control (Figure 3c). The increase of POD enzyme activity in the coated cantaloupe fruits could reflect tissue damage progress during storage [36].

\subsection{Effect of Coating Treatment on Microbiological Quality}

The development of microorganisms is shown in (Figure 4a). The internal aerobic microorganism counts were significantly higher in the control sample as (2.87 log CFU/g) and Nano/CTS (3.00 log CFU/g) compared with CTS (2.80 log CFU/g) and Nano/CTS/N (2.50 log CFU/g), respectively. A gradual increase was detected in the microbial growth for all the treatments during the storage. However, by the end of the storage, the control recorded (6.63 log CFU/g), followed by Nano/CTS and CTS treatments, whose microbial level had a little similarity ( $p \geq 0.05$ ) (ranging from 6.50 to $6.40 \log \mathrm{CFU} / \mathrm{g}$ ). Finally, the cantaloupes treated with Nano/CTS/N presented the lowest microbial counts (5.73 log $\mathrm{CFU} / \mathrm{g}$ ) at the end of the storage time [37].

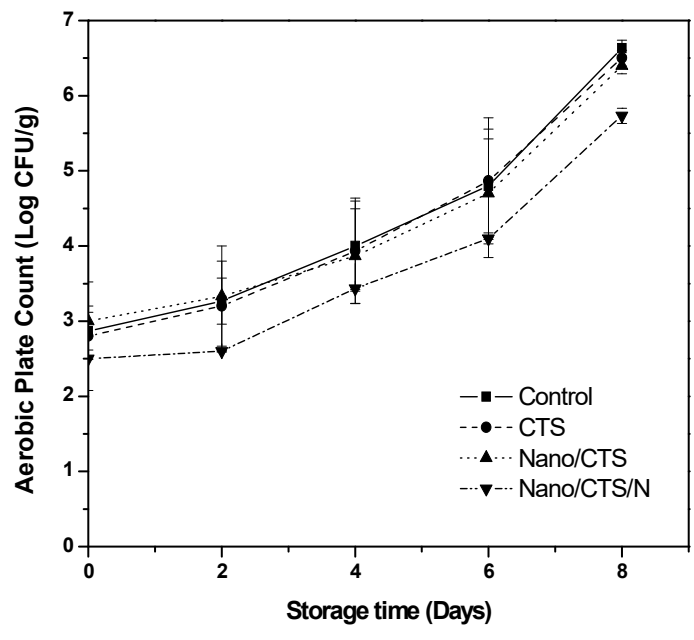

(a)

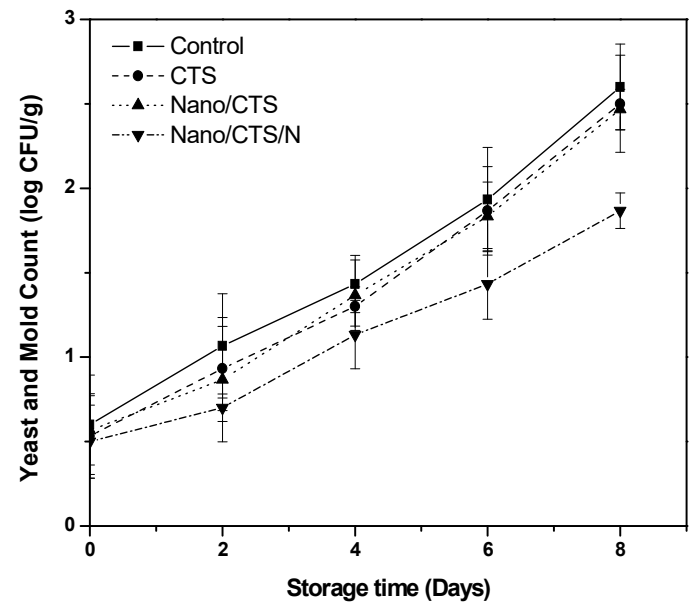

(b)

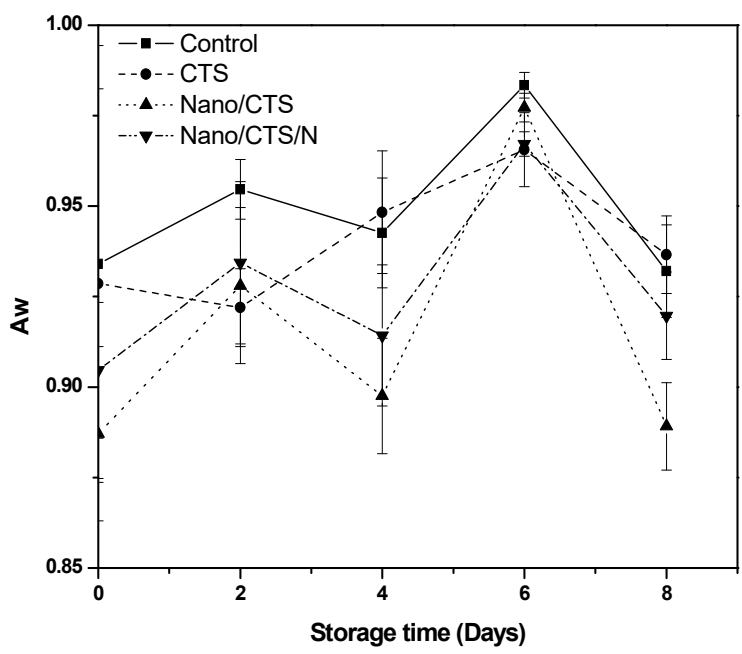

(c)

Figure 4. Effects of coating treatments on microbial quality, (a) total aerobic plate count, (b) yeast and mold counts, and (c) water activity of cantaloupe fruit; data are mean $\pm \mathrm{SD}, n=3$.

The presence of mold and yeasts is presented in (Figure $4 \mathrm{~b}$ ). Nano/CTS/N treatment reduced the growth to $(1.87 \log \mathrm{CFU} / \mathrm{g})$, followed by Nano/CTS, whose microbial level was 
(2.47 log CFU/g) on the 8th day of storage, respectively. Finally, the control recorded the highest counts as (2.60 log CFU/g). CTS treatment could decrease the microbial growth of yeasts and molds, which was in agreement with Syahidah et al. [38]. Chong et al. (2015) [22] suggested that the positive protonated $\left(\mathrm{NH}^{3+}\right)$ in the $(\mathrm{C}-2)$ of the polysaccharide can react with phosphoryl groups in the cell membrane. Similar reports have been approved [12,39]. Aw is responsible for the cell wall water holding capacity of cantaloupe tissue. The (Aw) of untreated cantaloupes $\sim 0.93$ was different compared to all the treated ones with nanomaterial treatments $(0.88-0.91)$ as shown in (Figure $4 \mathrm{c})$.

\subsection{Sensory Evaluation of Coating Treatment}

The sensorial properties made by different coating treatments such as color, odor, flavor, texture, and overall quality are shown in (Figure 5). Control and Nano/CTS sample treatments showed the least acceptance score in a comparison with the other sample treatments; while Nano/CTS/N treatment sample gave the highest score. It may be as a result of higher microbial activities [37]. According to the results, it can be established that using the Nano/CTS/N condition was the most acceptable to be used in cantaloupe preservation.

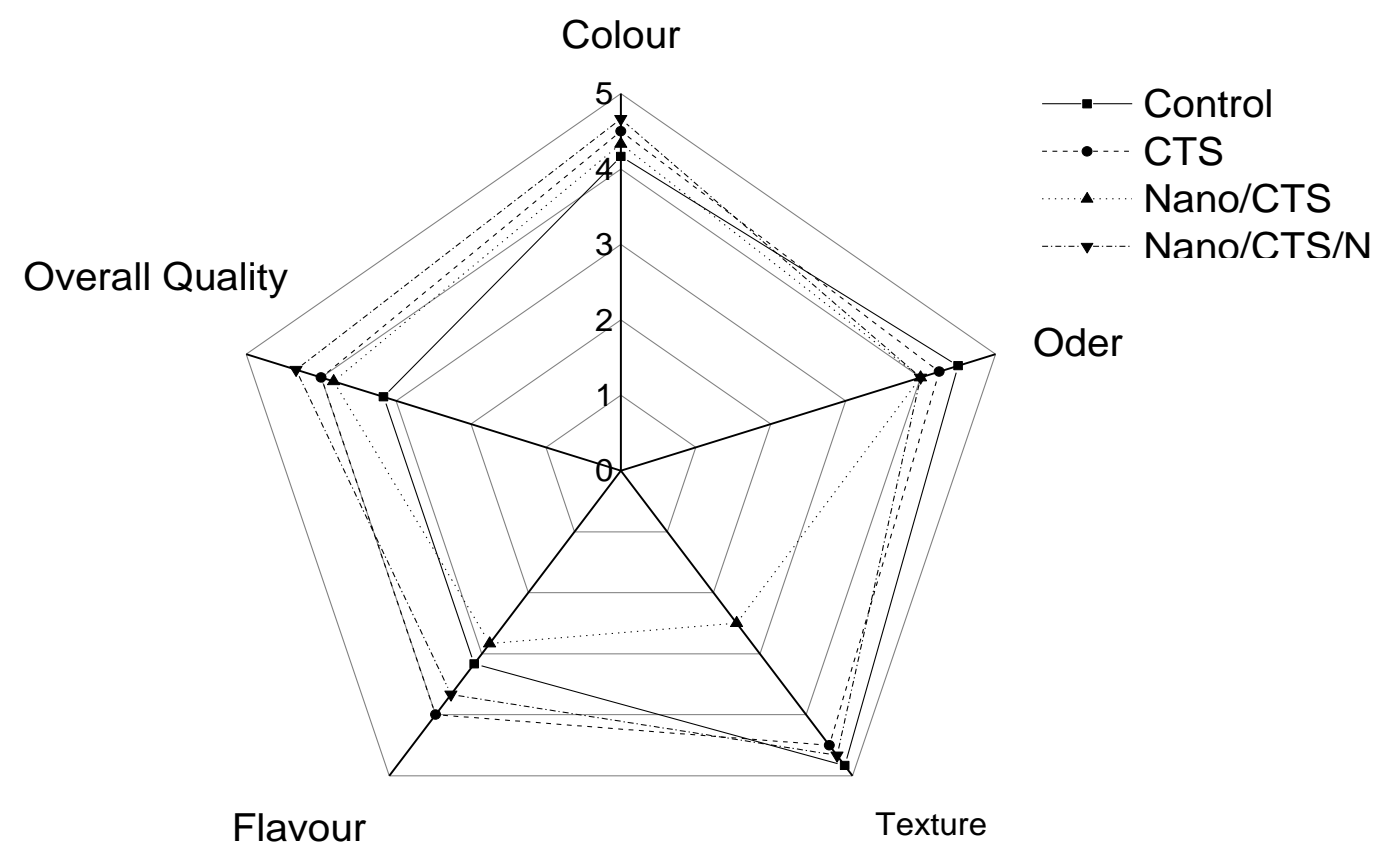

Figure 5. Sensory evaluation of fresh-cut cantaloupe fruits.

\section{Conclusions}

The modified chitosan/nano-silica/nisin hybrid films with non-destructive coating were applied for cantaloupe preservation during chilled storage to extend the shelf life. The retrieved investigated data depicted that the chitosan/nano-silica with the addition of nisin coating treatment was the most effective by forming semi-films against aerobic microorganisms, yeasts, molds, enzyme activities, and sensory evaluation.

Besides, artificial and natural chitosan-inorganic films can offer intriguing opportunities for nanotechnology application research and also provide new techniques in bringing solutions for the bioprocessing industry and fruit preservation.

Author Contributions: Conceptualization R.S.; M.A. (Manal Almatrafi); methodology, R.S.; M.A. (Mona Alharbi); M.H.; resources, M.H.; A.E.; funding acquisition, R.S., N.B. All authors have read and agreed to the published version of the manuscript.

Funding: This research received no external funding.

Institutional Review Board Statement: Not applicable. 
Informed Consent Statement: Not applicable.

Data Availability Statement: Available from corresponding author.

Acknowledgments: Taif University Researchers Supporting Project Number (TURSP-2020/140), Taif University, Taif, Saudi Arabia. This research was funded by the Deanship of Scientific Research at Princess Nourah bint Abdulrahman University through the Fast-track Research Funding Program.

Conflicts of Interest: The authors declared no conflict of interest.

\section{References}

1. Qiao, G.; Xiao, Z.; Ding, W.; Sami, R. Effect of Chitosan/Nano-Titanium Dioxide/Thymol and Tween Films on Ready-to-Eat Cantaloupe Fruit Quality. Coatings 2019, 9, 828. [CrossRef]

2. Martiñon, M.E.; Moreira, R.G.; Castell-Perez, M.E.; Gomes, C. Development of a multilayered antimicrobial edible coating for shelf-life extension of fresh-cut cantaloupe (Cucumis melo L.) stored at 4 C. LWT-Food Sci. Technol. 2014, 56, 341-350.

3. Sami, R. Application of Nano-coating and Chitosan Combination Films on Cantaloupe Preservation. Pak. J. Biol. Sci. 2020, 23, 1037-1043. [CrossRef]

4. John, C.B. Volatile Changes in Cantaloupe during Growth, Maturation, and in Stored Fresh-cuts Prepared from Fruit Harvested at Various Maturities. J. Am. Soc. Hortic. Sci. Jashs 2006, 131, 127-139. [CrossRef]

5. Manzocco, L.; Da Pieve, S.; Maifreni, M. Impact of UV-C light on safety and quality of fresh-cut melon. Innov. Food Sci. Emerg. Technol. 2011, 12, 13-17. [CrossRef]

6. Koh, P.C.; Noranizan, M.A.; Nur Hanani, Z.A.; Karim, R.; Rosli, S.Z. Application of edible coatings and repetitive pulsed light for shelf life extension of fresh-cut cantaloupe (Cucumis melo L. reticulatus cv. Glamour). Postharvest Biol. Technol. 2017, 129, 64-78. [CrossRef]

7. Wang, Z.; Ma, Y.; Zhao, G.; Liao, X.; Chen, F.; Wu, J.; Chen, J.; Hu, X. Influence of Gamma Irradiation on Enzyme, Microorganism, and Flavor of Cantaloupe (Cucumis melo L.) Juice. J. Food Sci. 2006, 71, M215-M220. [CrossRef]

8. Cao, S.; Hu, Z.; Pang, B.; Wang, H.; Xie, H.; Wu, F. Effect of ultrasound treatment on fruit decay and quality maintenance in strawberry after harvest. Food Control 2010, 21, 529-532. [CrossRef]

9. Ma, W.; Sami, R.; Xu, L.; Sui, X.; Jiang, L.; Li, Y. Physical-Chemical Properties of Edible Film Made from Soybean Residue and Citric Acid. J. Chem. 2018, 2018, 4026831. [CrossRef]

10. Sipahi, R.E.; Castell-Perez, M.E.; Moreira, R.G.; Gomes, C.; Castillo, A. Improved multilayered antimicrobial alginate-based edible coating extends the shelf life of fresh-cut watermelon (Citrullus lanatus). LWT Food Sci. Technol. 2013, 51, 9-15. [CrossRef]

11. Sami, R.; Jia, F.; Li, Y.; Nie, X.; Xu, J.; Han, R.; Yu, H.; Amanullah, S.; Almatrafi, M.M.; Helal, M. Application of nano-titanum dioxide coating on fresh Highbush blueberries shelf life stored under ambient temperature. LWT 2021, 137, 110422. [CrossRef]

12. Li, Y.; Sami, R.; Jia, F.; Nie, X.; Xu, J.; Elhakem, A.; Almatrafi, M.; Benajiba, N.; Helal, M. Shelf-life, quality, safety evaluations of blueberry fruits coated with chitosan nano-material films. Sci. Rep. 2021, 11, 55. [CrossRef]

13. Sami, R.; Khojah, E.; Elhakem, A.; Benajiba, N.; Helal, M. Chitosan, Nisin, Silicon Dioxide Nanoparticles Coating Films Effects on Blueberry (Vaccinium myrtillus) Quality. Coatings 2020, 10, 962. [CrossRef]

14. Sami, R.; Elhakem, A.; Alharbi, M.; Benajiba, N.; Almatrafi, M.; Jing, J.; Helal, M. Effect of Titanium Dioxide Nanocomposite Material and Antimicrobial Agents on Mushrooms Shelf-Life Preservation. Processes 2020, 8, 1632. [CrossRef]

15. Sami, R.; Khojah, E.; Elhakem, A.; Benajiba, N.; Chavali, M.; Vivek, K.; Iqbal, A.; Helal, M. Investigating the Nano-Films Effect on Physical, Mechanical Properties, Chemical Changes, and Microbial Load Contamination of White Button Mushrooms during Storage. Coatings 2021, 11, 44. [CrossRef]

16. Rojas-Graü, M.A.; Tapia, M.S.; Martín-Belloso, O. Using polysaccharide-based edible coatings to maintain quality of fresh-cut Fuji apples. LWT Food Sci. Technol. 2008, 41, 139-147. [CrossRef]

17. Tapia, M.S.; Rojas-Graü, M.A.; Carmona, A.; Rodríguez, F.J.; Soliva-Fortuny, R.; Martin-Belloso, O. Use of alginate- and gellanbased coatings for improving barrier, texture and nutritional properties of fresh-cut papaya. Food Hydrocoll. 2008, 22, 1493-1503. [CrossRef]

18. Shi, S.; Wang, W.; Liu, L.; Wu, S.; Wei, Y.; Li, W. Effect of chitosan/nano-silica coating on the physicochemical characteristics of longan fruit under ambient temperature. J. Food Eng. 2013, 118, 125-131. [CrossRef]

19. Kou, X.; He, Y.; Li, Y.; Chen, X.; Feng, Y.; Xue, Z. Effect of abscisic acid (ABA) and chitosan/nano-silica/sodium alginate composite film on the color development and quality of postharvest Chinese winter jujube (Zizyphus jujuba Mill. cv. Dongzao). Food Chem. 2019, 270, 385-394. [CrossRef] [PubMed]

20. Ahmad, V.; Khan, M.S.; Jamal, Q.M.S.; Alzohairy, M.A.; Al Karaawi, M.A.; Siddiqui, M.U. Antimicrobial potential of bacteriocins: In therapy, agriculture and food preservation. Int. J. Antimicrob. Agents 2017, 49, 1-11. [CrossRef]

21. Abdelazez, A.; Muhammad, Z.; Zhang, Q.-X.; Zhu, Z.-T.; Abdelmotaal, H.; Sami, R.; Meng, X.-C. Production of a Functional Frozen Yogurt Fortified with Bifidobacterium spp. BioMed. Res. Int. 2017, 2017, 6438528. [CrossRef] [PubMed]

22. Chong, J.X.; Lai, S.; Yang, H. Chitosan combined with calcium chloride impacts fresh-cut honeydew melon by stabilising nanostructures of sodium-carbonate-soluble pectin. Food Control 2015, 53, 195-205. [CrossRef] 
23. Sami, R.; Li, Y.; Qi, B.; Wang, S.; Zhang, Q.; Han, F.; Ma, Y.; Jing, J.; Jiang, L. HPLC Analysis of Water-Soluble Vitamins (B2, B3, B6, B12, and C) and Fat-Soluble Vitamins (E, K, D, A, and $\beta$-Carotene) of Okra (Abelmoschus esculentus). J. Chem. 2014, $2014,831357$. [CrossRef]

24. Sami, R.; Elhakem, A.; Alharbi, M.; Benajiba, N.; Almatrafi, M.; Abdelazez, A.; Helal, M. Evaluation of Antioxidant Activities, Oxidation Enzymes, and Quality of Nano-Coated Button Mushrooms (Agaricus Bisporus) during Storage. Coatings 2021, 11, 149. [CrossRef]

25. Sadhu, A.; Ganguly, K.K. Lactobacillus sp.-A threat to pathogenic microorganisms and tumor cells. J. Cancer Ther. 2017, 8, 96-111. [CrossRef]

26. Koh, P.C.; Noranizan, M.A.; Karim, R.; Nur Hanani, Z.A. Microbiological stability and quality of pulsed light treated cantaloupe (Cucumis melo L. reticulatus cv. Glamour) based on cut type and light fluence. J. Food Sci. Technol. 2016, 53, 1798-1810. [CrossRef] [PubMed]

27. Moreira, S.P.; de Carvalho, W.M.; Alexandrino, A.C.; de Paula, H.C.B.; Rodrigues, M.d.C.P.; de Figueiredo, R.W.; Maia, G.A.; de Figueiredo, E.M.A.T.; Brasil, I.M. Freshness retention of minimally processed melon using different packages and multilayered edible coating containing microencapsulated essential oil. J. Food Sci. Technol. 2014, 49, 2192-2203. [CrossRef]

28. Wang, H.; Sun, Y.; Li, Y.; Tong, X.; Regenstein, J.M.; Huang, Y.; Ma, W.; Sami, R.; Qi, B.; Jiang, L. Effect of the condition of spray-drying on the properties of the polypeptide-rich powders from enzyme-assisted aqueous extraction processing. Dry. Technol. 2019, 37, 2105-2115. [CrossRef]

29. Treviño-Garza, M.Z.; Correa-Cerón, R.C.; Ortiz-Lechuga, E.G.; Solís-Arévalo, K.K.; Castillo-Hernández, S.L.; Gallardo-Rivera, C.T.; Arévalo Niño, K. Effect of Linseed (Linum usitatissimum) Mucilage and Chitosan Edible Coatings on Quality and Shelf-Life of Fresh-Cut Cantaloupe (Cucumis melo). Coatings 2019, 9, 368. [CrossRef]

30. Falade, K.O.; Igbeka, J.C.; Ayanwuyi, F.A. Kinetics of mass transfer, and colour changes during osmotic dehydration of watermelon. J. Food Eng. 2007, 80, 979-985. [CrossRef]

31. Zhang, Y.; Ma, Q.; Critzer, F.; Davidson, P.M.; Zhong, Q. Effect of alginate coatings with cinnamon bark oil and soybean oil on quality and microbiological safety of cantaloupe. Int. J. Food Microbiol. 2015, 215, 25-30. [CrossRef]

32. Tripathi, K.; Pandey, S.; Malik, M.; Kaul, T. Fruit ripening of climacteric and non climacteric fruit. J. Environ. Appl. Bioresearch 2016, 4, 27-34.

33. Li, L.; He, X.; Sun, J.; Li, C.; Ling, D.; Sheng, J.; Zheng, F.; Liu, G.; Li, J.; Tang, Y.; et al. Responses of Phospholipase D and Antioxidant System to Mechanical Wounding in Postharvest Banana Fruits. J. Food Qual. 2017, 2017, 8347306. [CrossRef]

34. Koh, P.C.; Noranizan, M.A.; Karim, R.; Nur Hanani, Z.A.; Rosli, S.Z.; Hambali, N.H. Enzymatic activity of alginate coated and pulsed light treated fresh-cut cantaloupes (Cucumis melo L. var. reticulatus cv. Glamour) during chilled storage. Int. Food Res. J. 2019, 26, 547-556.

35. Meng, X.; Li, B.; Liu, J.; Tian, S. Physiological responses and quality attributes of table grape fruit to chitosan preharvest spray and postharvest coating during storage. Food Chem. 2008, 106, 501-508. [CrossRef]

36. And, O.L.; Watson, M.A. Effects of Ascorbic Acid on Peroxidase and Polyphenoloxidase Activities in Fresh-Cut Cantaloupe Melon. J. Food Sci. 2001, 66, 1283-1286. [CrossRef]

37. Maurício, E.; Rosado, C.; Duarte, M.P.; Verissimo, J.; Bom, S.; Vasconcelos, L. Efficiency of Nisin as Preservative in Cosmetics and Topical Products. Cosmetics 2017, 4, 41. [CrossRef]

38. Haffez, M.M.; Ragab, M.E.; El-Yazied, A.A.; Emam, M.S. Effect of chitosan, carboxy methyl cellulose and calcium chloride treatments on quality and storability of fresh cut Cantaloupe. Middle East J. Appl. Sci. 2016, 6, 249-268.

39. Syahidah, K.; Rosnah, S.; Noranizan, M.A.; Zaulia, O.; Anvarjon, A. Quality changes of fresh cut cantaloupe (Cucumis melo L. var Reticulatus cv. Glamour) in different types of polypropylene packaging. Int. Food Res. J. 2015, 22, 753-760. 